\title{
Research on the Relationship between Accounting Information Quality and Enterprise Investment Efficiency
}

\author{
Aoxue Liür,a, \\ ${ }^{1}$ School of Economics and Management, Beijing Jiaotong University, China \\ a17120658@bjtu.edu.cn \\ ${ }^{*}$ Corresponding author
}

Keywords: Insufficient investment, Excessive investment, Accounting information quality.

\begin{abstract}
Based on the study of the relationship between the quality of accounting information and investment efficiency, this paper empirically analyses the relationship between the quality of accounting information and the efficiency of enterprise investment based on the statistics of A-share listed company in 2013-2016. In this paper, the modified Jones model and Richardson investment expectation model are used to measure the main variables, and descriptive statistical analysis, correlation analysis and regression analysis are carried out to study the relationship between the two. It is found that non-financial listed companies in China generally have the phenomenon of inefficient investment and the phenomenon of underinvestment is more common, the quality of high-quality accounting information can alleviate the underinvestment and overinvestment of listed companies, the impact of high quality accounting information on inefficient investment of state-controlled listed enterprises is stronger than that of the non-state-controlled listed companies.
\end{abstract}

\section{Introduction}

Investment decision is the core of enterprise financial decision, which determines the financing behavior of enterprise, and it also has a vital influence on the investment income of the enterprise. The investment decision of the enterprise can not only influence the market value of the enterprise and the change of the shareholder's wealth, but also can influence the stability of the macro-economy, the enterprise investment decision can be reflected from the enterprise's investment efficiency.

However, Chinese capital market and corporate governance mechanism is not perfect enough, making inefficient investment problem extremely serious. On the one hand, enterprises are short of the grasp of the market or invest the enterprise resources to the unprofitable project for some special purpose; On the other hand, some enterprises will face the financing dilemma and miss the investment opportunity. Therefore, the suppression of inefficient investment has become an urgent problem to be solved. The existing research found that free cash flow, the nature of the external large shareholder and debt leverage have a certain impact on the investment efficiency of enterprises ${ }^{[1,2,3]}$. In addition, high quality of accounting information can alleviate information asymmetry and principal-agent problem and thus gradually become the research hotspot ${ }^{[4]}$. In China, the accounting system gradually tends to unify in the development and improvement of the market economy. Accounting standards, accounting reports and so connect with the international standards on gradually, and gradually improve the degree of standardization. Therefore, whether the accounting information quality is related to the investment efficiency of the enterprise becomes the research content of this paper.

\section{Literature Review and Research Hypothesis}

In the previous study of investment efficiency, foreign scholars focused mainly on the influence of external environment on investment efficiency. In recent years, many scholars began to focus on the impact of internal environmental factors on investment efficiency, the focus shifted to the impact of 
internal factors such as quality of accounting information. McNichols and Stubben documented that the degree of overinvestment of enterprises with lower earnings management was correspondingly lower ${ }^{[5]}$.

Partha Sengupat documented that there was a negative relationship between quality of accounting information and cost of debts ${ }^{[6]}$. And lower cost of debts could reduce the possibility of under-investment for the lack of money. Also, Bushman and smith suggested that higher accounting information quality could regulate investment decisions made by managers, mitigating agency problems and optimize investment ${ }^{[7]}$. In addition, higher accounting information quality can enhance the ability of investment decision makers to identify investment opportunities when he making investment decisions, reducing the possibility of missing investment opportunities due to insufficient recognition ability, and reduce or avoid blind over-investment, so improve the efficiency of enterprise investment ${ }^{[4]}$. Therefore, the paper presents the following two hypotheses:

H1: There is a negative correlation between the quality of accounting information and underinvestment.

$\mathrm{H} 2$ : There is a negative correlation between the quality of accounting information and overinvestment of enterprises.

In addition, non-state-controlled companies can change the mode of operation in accordance with the provisions of law to meet the overall business objectives that pursue the maximization of profit and shareholder value. But state-controlled listed companies are under heavier influence by policy, which will reduce the impact of quality of accounting information in guiding the company's resource allocation process. In view of this situation, this paper points out the third pending test hypothesis:

H3: Compared with state-controlled listed companies, the quality of the accounting information of the non-state-controlled listed companies has a deeper impact on the investment efficiency.

\section{Research design}

\subsection{Data and sample selection}

All the data in this paper are from CSMAR database, from which we obtain the financial data in the 2011-2016 period of all shares listed companies of Shanghai and Shenzhen Stock Exchange. The following companies are excluded in the process of selecting samples: (1) Listed abroad and in domestic at the same time; (2) PT, ST, *ST and companies where main business income or shareholder rights and interests of the company is not positive; (3) Classified into financial industry, insurance industry or real estate industry; (4) With incomplete or abnormal financial data during the study period. Finally, a total of 7,840 annual observations were obtained in the empirical testing phase. In addition, all variables are indented at $1 \%$ and $99 \%$ to avoid the effects of extreme values.

\subsection{Variable definition}

\subsubsection{Explained variables: inefficient investments (OverInv/UnderInv)}

The Richardson model is used as an alternative variable to investment efficiency. The model refers to Eq. 1:

$$
\begin{gathered}
\operatorname{Inv}_{\mathrm{i}, \mathrm{t}}=\beta_{0}+\beta_{1} \text { Growth }_{\mathrm{i}, \mathrm{t}-1}+\beta_{2} \operatorname{Lev}_{\mathrm{i}, \mathrm{t}-1}+\beta_{3} \operatorname{Cash}_{\mathrm{i}, \mathrm{t}-1}+\beta_{4} \operatorname{Age}_{\mathrm{i}, \mathrm{t}-1}+\beta_{5} \operatorname{Size}_{\mathrm{i}, \mathrm{t}-1}+\beta_{6} \operatorname{Returns}_{\mathrm{i}, \mathrm{t}-1}+\beta_{7} \operatorname{Inv}_{\mathrm{i}, \mathrm{t}}+\beta_{8} \text { Year } \\
+\beta_{9} \text { Industry }+\varepsilon_{\mathrm{i}, \mathrm{t}} .
\end{gathered}
$$

$\varepsilon_{\mathrm{i}, \mathrm{t}}$, the residual of the model, represents the investment efficiency. When $\varepsilon_{\mathrm{i}, \mathrm{t}}>0$, it means over-investment, which is represented by OverInv. When $\varepsilon_{\mathrm{i}, \mathrm{t}}<0$, it means that the investment is insufficient, which is represented by UnderInv. For ease of understanding and explanation, Underlnv is taken as an absolute value. Therefore, the greater the value of Overlnv and Underlnv, the lower the investment efficiency of the listed company. In addition, the listed company's own main business growth, debt ratio, cash inventory, company establishment period, company size, 
return rate for investment, industry's own variables and annual variables are represented separately by Growth, Lev, Cash, Age, Size, Return, Year, and Industry.

\subsubsection{Explanatory variable: Quality of accounting information (AQ)}

In this paper, the accounting information quality is measured by the controllable total accrual profit of the modified Jones model. The difference between the actual total accrual profit and the uncontrollable accrual profit predicted by the regression model can be regarded as controllable accrual profit manipulated by the management. When the absolute value of the difference amount is taken as the profit management proxy variable, the greater the absolute value is, the greater the company's earning management degree is, and the poorer the company's earnings quality. Its estimated process is as follows:

First, calculate the total accrual profit:

$$
\mathrm{TA}_{\mathrm{i}, \mathrm{t}}=\mathrm{NI}_{\mathrm{i}, \mathrm{t}}-\mathrm{CFO}_{\mathrm{i}, \mathrm{t}} \cdot
$$

Then make a regression based on Eq. 3 by industry and year:

$$
\frac{\mathrm{TA}_{\mathrm{i}, \mathrm{t}}}{\text { Asset }_{\mathrm{i}, \mathrm{t}-1}}=\frac{\alpha_{1}}{\text { Asset }_{\mathrm{i}, \mathrm{t}-1}}+\frac{\alpha_{2} \Delta \mathrm{REV}_{\mathrm{i}, \mathrm{t}}}{\text { Asset }_{\mathrm{i}, \mathrm{t}-1}}+\frac{\alpha_{3} \mathrm{PPE}_{\mathrm{i}, \mathrm{t}}}{\text { Asset }_{\mathrm{i}, \mathrm{t}-1}}+\varepsilon_{\mathrm{i}, \mathrm{t}} \cdot
$$

The coefficient estimated by Eq. 3 is put into the f Eq. 4 to calculate Discretionary Accruals:

$$
\mathrm{DA}_{\mathrm{i}, \mathrm{t}}=\frac{\mathrm{TA}_{\mathrm{i}, \mathrm{t}}}{\text { Asset }_{\mathrm{i},-1}-}-\frac{\widehat{\alpha_{1}}}{\text { Asset }_{\mathrm{i}, \mathrm{t}-1}}-\frac{\widehat{\alpha_{2}}\left(\Delta \mathrm{REV}_{\mathrm{i}, \mathrm{t}}-\Delta \mathrm{REC}_{\mathrm{i}, \mathrm{t}}\right)}{\text { Asset }_{\mathrm{i}, \mathrm{t}-1}}-\frac{\widehat{\alpha_{3}} \mathrm{PPE}_{\mathrm{i}, \mathrm{t}}}{\text { Asset }_{\mathrm{i}, \mathrm{t}-1}} .
$$

Among them, NI, CFO, $\triangle \mathrm{REV}, \triangle \mathrm{REC}, \mathrm{PPE}, \mathrm{NDA}$, and DA respectively represent the operating profit, net cash flow generated from operating activities, total assets at the end of the year, increments in sales revenue, increments in accounts receivable, original value of fixed assets (net fixed assets in this paper), non-operating accruals profit and discretionary accruals.

Since the discretionary accruals should be counted as positive or negative, for the sake of analysis, we multiply the absolute value by -1 as the earnings quality to reflect the quality of the listed company's accounting information. The larger the value, the higher the quality of the accounting information (AQ).

\subsubsection{Control variables}

Based on the research methods of related literatures, this paper chooses the control variables of enterprise scale (Size), free cash flow (FCF), Total asset turnover (SAR), equity concentration (Herf) and the nature of property (Soe) to test the model. In addition, this paper also includes indicator

\begin{tabular}{|c|c|c|}
\hline Types & Variable & Variable definitions \\
\hline \multirow{2}{*}{ Explained variables: } & OverInv & Absolute value of regression residual which is greater than 0 in Richardson model \\
\hline & UnderInv & Absolute value of regression residual which is less than 0 in Richardson model \\
\hline Explanatory variable & AQ & The negative value of the absolute value of discretionary accruals \\
\hline \multirow{5}{*}{ Control variables } & Size & Natural logarithm of total assets \\
\hline & FCF & Free cash flow / total assets at the end of the year \\
\hline & SAR & Main business income/average total assets \\
\hline & Herf & Top 10 shareholding ratio \\
\hline & Soe & Nature of property, divided into state-owned (0) and non-state-owned (1) \\
\hline
\end{tabular}
variables for industry membership and temporal effects. The main variable as shown in Table 1.

Table 1. Variable definitions.

Based on the research methods of related literatures, this paper chooses the control variables of enterprise scale (Size), free cash flow (FCF), Total asset turnover (SAR), equity concentration (Herf) and the nature of property (Soe) to test the model. In addition, this paper also includes indicator variables for industry membership and temporal effects. The main variable as shown in Table 1. 


\subsection{Model design}

Based on the previous discussion, the following regression models are proposed to test hypothesis 1 and hypothesis 2:

$$
\text { OverInv }_{\mathrm{i}, \mathrm{t}}\left(\text { UnderInv }_{\mathrm{i}, \mathrm{t}}\right)=\beta_{0}+\gamma_{1} \mathrm{AQ}_{\mathrm{i}, \mathrm{t}-1}+\gamma_{2} \operatorname{Size}_{\mathrm{i}, \mathrm{t}}+\gamma_{3} \mathrm{FCF}_{\mathrm{i}, \mathrm{t}}+\gamma_{4} \mathrm{SAR}_{\mathrm{i}, \mathrm{t}}+\gamma_{5} \operatorname{Herf}_{\mathrm{i}, \mathrm{t}}+\gamma_{6} \operatorname{Soe}_{\mathrm{i}, \mathrm{t}}+\varepsilon_{\mathrm{i}, \mathrm{t}} \text {. }
$$

If hypothesis 1 and hypothesis 2 are confirmed to be valid, the corresponding coefficients of AQ should be negative.

\section{Empirical tests}

\subsection{Descriptive statistics}

As the Table 2 shows, 2,974 of the 7,840 samples belong to over-investment, which accounted for $37.93 \%$ of the total number of samples, and 4,866 of the total sample belong to under-investment and are accounted for $62.07 \%$.

Table 2. Descriptive statistics of main variables.

\begin{tabular}{cccccc}
\hline Variable & Obs & Mean & Std.Dev. & Min & Max \\
\hline OverInv & 2974 & 0.0416647 & 0.0452804 & 0.0000597 & 0.2660503 \\
\hline UnderInv & 4866 & 0.0254646 & 0.0207515 & $1.24 \mathrm{e}-06$ & 0.2034439 \\
\hline AQ & 7840 & -0.0620272 & 0.1352972 & -6.497737 & $-1.05 \mathrm{e}-06$ \\
\hline Size & 7840 & 22.13237 & 1.198223 & 17.6413 & 27.96173 \\
\hline FCF & 7840 & -0.0012595 & 0.1372052 & -3.719524 & 1.764304 \\
\hline SAR & 7840 & 0.6715986 & 0.5900773 & 0.000989 & 12.37286 \\
\hline Herf & 7840 & 0.5553067 & 0.1482738 & 0.0132 & 0.96504 \\
\hline Soe & 7840 & 0.3989796 & 0.4897198 & 0 & 1
\end{tabular}

The mean value of over-investment is 0.0417 , and the average value of investment is 0.0255 . We can infer that there are more companies with under-investment than those which invest excessively, and the degree of over-investment is greater than the lack of investment. In short, the phenomenon of inefficient investment in China's listed companies are common.

\subsection{Correlation analysis}

According to the results of the correlation analysis, AQ is negatively correlated with OverInv, and the correlation coefficient is 0.0788, which indicates that the improvement of accounting information quality can alleviate the excessive investment of enterprises. A similar result can be found when it comes to UnderInv, with a correlation coefficient of 0.0967, which suggests that the higher the quality of accounting information, the lower the degree of enterprise under-investment, indicating that the quality of accounting information can alleviate the under-investment of enterprises.

\subsection{Multiple regression analysis}

\subsubsection{Regression analysis on overinvestment}

The first two of the eight regressions in Table 3 presents the results of regression in case of over-investment based on Eq. 5. The regression results show that there is a negative correlation between the AQ and OverInv, which is highly significant at $1 \%$ level. This indicates that the improvement of accounting information quality can inhibit the excessive investment of enterprises. Both two regressions pass $\mathrm{F}$ test, and the overall regression equation is very significant. Therefore, this result validates the hypothesis 1 .

\subsubsection{Regression analysis on underinvestment}

Regression 3 and Regression 4 in Table 3 presents the results of regression in case of over-investment based on Eq. 5. The regression results show that there is a negative correlation between the AQ and UnderInv, which is highly significant at $1 \%$ level. This indicates that the improvement of accounting information quality can inhibit the under-investment of enterprises. 
Both two regressions pass $\mathrm{F}$ test. Therefore, this result validates the hypothesis 2 .

Analyze Regression 1-4 comprehensively we can found: (1) The results above fully support the hypothesis 1 and hypothesis 2, that is, high quality of accounting information can inhibit the enterprise's inefficient investment, (2) the size of the enterprise, the amount of cash flow and the turnover speed of the enterprise is negatively correlated with the degree of the inefficient investment, but the concentration of equity is positively correlated with inefficient investment, and the results are all very significant.

\subsubsection{Actual controller, accounting information quality and inefficient investment}

It is assumed that the impact of accounting information quality on the enterprise's inefficient investment is different when it comes to different actual controller in hypothesis 3. Studying 3,128 state-owned listed companies selected from the 7,840 samples, we can find that the phenomenon of under-investment is more common than over-investment whether in state-owned enterprises or non-state-owned enterprises. However, the phenomenon of under-investment in state-owned enterprises is more serious than that in non-state-owned enterprises.

In order to study the influence of the quality of accounting information on the inefficient investment of state-owned enterprises, the paper perform regression on Eq. 5 and the results of the regressions is shown in Table 3.

In the aspect of over-investment (Reg5 and Reg6), the regression result of state-owned enterprise (Reg5) is superior to the non-state-owned enterprise (Reg6) both in terms of the magnitude of the coefficient and the significance level. In the aspect of under-investment (Reg7 and Reg8), the coefficient of accounting information quality in Reg 7 is smaller than that in Reg 8 . The four regressions show that compared with non-state-owned enterprises, the quality of accounting information of listed companies in state-owned enterprises is more capable of relieving the inefficient investment, which is the opposite of hypothesis 3.

Table 3. Results of regressions on Eq. 5.

\begin{tabular}{|c|c|c|c|c|c|c|c|c|}
\hline variable & Reg 1 & Reg 2 & Reg 3 & Reg 4 & Reg 5 & Reg 6 & Reg 7 & Reg 8 \\
\hline Constant & $\begin{array}{c}0.039 * * * \\
(0.000)\end{array}$ & $\begin{array}{c}0.081^{* * *} \\
(0.000)\end{array}$ & $\begin{array}{c}0.025 * * * \\
(0.000)\end{array}$ & $\begin{array}{c}0.101^{* * *} \\
(0.000)\end{array}$ & $\begin{array}{c}0.081^{* * *} \\
(0.001)\end{array}$ & $\begin{array}{l}0.043^{*} \\
(0.093)\end{array}$ & $\begin{array}{c}0.010 * * * \\
(0.000)\end{array}$ & $\begin{array}{c}0.103^{* * *} \\
(0.000)\end{array}$ \\
\hline AQ_l & $\begin{array}{c}-0.044 * * * \\
(0.000)\end{array}$ & $\begin{array}{c}-0.035^{* * *} \\
(0.001)\end{array}$ & $\begin{array}{c}-0.016^{* * *} \\
(0.000)\end{array}$ & $\begin{array}{c}-0.013^{* * *} \\
(0.000)\end{array}$ & $\begin{array}{c}-0.077 * * * \\
(0.000)\end{array}$ & $\begin{array}{c}-0.020 \\
(0.109)\end{array}$ & $\begin{array}{c}-0.023 * * * \\
(0.000)\end{array}$ & $\begin{array}{c}-0.013 * * * \\
(0.000)\end{array}$ \\
\hline Size & & $\begin{array}{c}-0.002 * * * \\
(0.004)\end{array}$ & & $\begin{array}{c}-0.003^{* * *} \\
(0.000)\end{array}$ & $\begin{array}{c}-0.003 * * * \\
(0.009)\end{array}$ & $\begin{array}{c}-0.001 \\
(0.329)\end{array}$ & $\begin{array}{c}-0.003 * * * \\
(0.000)\end{array}$ & $\begin{array}{c}-0.004^{* * *} \\
(0.000)\end{array}$ \\
\hline FCF & & $\begin{array}{c}-0.015 * * \\
(0.023)\end{array}$ & & $\begin{array}{c}-0.008 * * * \\
(0.004)\end{array}$ & $\begin{array}{c}-0.049 * * * \\
(0.000)\end{array}$ & $\begin{array}{c}0.0005 \\
(0.955)\end{array}$ & $\begin{array}{c}0.0003 \\
(0.944)\end{array}$ & $\begin{array}{c}-0.013^{* * *} \\
(0.001)\end{array}$ \\
\hline SAR & & $\begin{array}{c}-0.010^{* * *} \\
(0.000)\end{array}$ & & $\begin{array}{c}-0.003^{* * *} \\
(0.000)\end{array}$ & $\begin{array}{c}-0.007 * * * \\
(0.004)\end{array}$ & $\begin{array}{c}-0.013^{* * *} \\
(0.000)\end{array}$ & $\begin{array}{c}-0.003^{* * *} * \\
(0.000)\end{array}$ & $\begin{array}{c}-0.003 * * * \\
(0.000)\end{array}$ \\
\hline Herf & & $\begin{array}{c}0.040 * * * \\
(0.000)\end{array}$ & & $\begin{array}{c}0.009^{* * *} \\
(0.000)\end{array}$ & $\begin{array}{c}0.030 * * * \\
(0.001)\end{array}$ & $\begin{array}{c}0.048 * * * \\
(0.000)\end{array}$ & $\begin{array}{c}0.010^{* * *} \\
(0.001)\end{array}$ & $\begin{array}{c}0.007^{* * *} \\
(0.007)\end{array}$ \\
\hline Soe & & $\begin{array}{c}-0.009 * * * \\
(0.000)\end{array}$ & & $\begin{array}{c}-0.002^{* * *} \\
(0.000)\end{array}$ & - & - & - & - \\
\hline Year indicators & No & Yes & No & Yes & YES & YES & YES & YES \\
\hline $\begin{array}{l}\text { Industry } \\
\text { indicators }\end{array}$ & No & Yes & No & Yes & YES & YES & YES & YES \\
\hline F-test & $\begin{array}{c}18.55^{* * *} \\
(0.000) \\
\end{array}$ & $\begin{array}{c}16.42^{* * *} \\
(0.000)\end{array}$ & $\begin{array}{c}45.95 * * * \\
(0.000) \\
\end{array}$ & $\begin{array}{c}36.53^{* * *} \\
(0.000)\end{array}$ & $\begin{array}{l}7.82 * * * \\
(0.0000)\end{array}$ & $\begin{array}{l}9.79 * * * \\
(0.0000)\end{array}$ & $\begin{array}{c}16.05^{* * *} \\
(0.0000)\end{array}$ & $\begin{array}{c}17.14^{* * *} \\
(0.0000)\end{array}$ \\
\hline Adjusted R2 & 0.006 & 0.0493 & 0.0092 & 0.0681 & 0.0533 & 0.0403 & 0.0624 & 0.0489 \\
\hline
\end{tabular}

Note: *,**,***indicates significance at the $10 \%, 5 \%, 1 \%$ level respectively.

\subsection{Robustness test}

In order to test the robustness of the results of empirical analysis, the paper uses the method of Xuan Shi (2013) to measure the efficiency of investment once again, that is the value which reduces the ratio between the investment level and the average of the investment level in the past 3 years by 1 , the specific formula is: 


$$
C I_{i, t}=\frac{C E_{i, t}}{\frac{\mathrm{CE}_{i, t-2}+\mathrm{CE}_{\mathrm{i}, \mathrm{t}-1}+\mathrm{CE}_{\mathrm{i}, \mathrm{t}}}{3}}-1
$$

$\mathrm{CE}_{\mathrm{i}, \mathrm{t}}$ is calculated as dividing the amount of investment of the company $\mathrm{I}$ in year of $\mathrm{t}$ by its current year's main business income. The amount of investment is expressed by the amount of cash paid for the purchase of fixed assets, intangible assets and other long-term assets in the cash flow statement. $\mathrm{CI}_{\mathrm{i}, \mathrm{t}}$ on behalf of inefficient investment of Company I in the year of $\mathrm{t}$. If $\mathrm{CI}>0$, it means that the enterprise invests excessively; $\mathrm{CI}<0$ suggests that the company is not investing enough. The greater the value of CI, the higher the level of the enterprise's inefficient investment. Replacing the measurement of efficiency, the similar results are found after performing regression 1-4 again.

\section{Conclusion}

This paper firstly analyzed the mechanism of the quality of accounting information on investment efficiency in theory, and then verifies the influence of accounting information quality on investment efficiency with the data of China's listed companies. The main conclusions are as follows:

There is a widespread phenomenon of inefficient investment in China, where under-investment is more common than over-investment; State-controlled listed companies are in deeper degree of under-investment than non-state-controlled listed companies.

High quality of accounting information can significantly alleviate the inefficient investment, whether it is under-investment or over-investment, supporting hypothesis one and hypothesis two.

The mitigating effect of the accounting information quality on under-investment in state-controlled listed companies is significantly stronger than that of the state-controlled listed companies. The conclusion is not in accord with the hypothesis 3 , the reason may be that the state-owned enterprises occupy the advantage in the financing platform and scarce resources, which form the government's support to the state-owned enterprises and enhance the degree of the relief of the high quality of accounting information to the inefficient investment.

\section{References}

[1] C. G. Liu, Corporate governance mechanism, free cash flow and over-investment behavior of listed companies, Economic Science, vol.4, pp. 50-58, 2006.

[2] L. P. Xu, Z. Xin, and G. M. Chen, Equity concentration and equity checks and balances and their impact on the company's operating performance, Economic Research, vol.1, pp. 90-100, 2006.

[3] Q. Q. Xin and B. Lin, Debt leverage and corporate investment: A dual budget soft constraint perspective, Financial Research, vol.7, pp. 73-83, 2006.

[4] B. Y. Luo, The Mechanism of the effect of accounting information quality on enterprise investment efficiency, Business research, vol.6, pp. 64-75, 2014.

[5] M. F. McMichols and S. R. Stubben, Earnings management affect firm's investment decisions, The Accounting Review, vol.83, pp. 1571-1603, 2008.

[6] P. Sengupta, Corporate disclosure quality and the cost of debt, The Accounting Review, vol.73(4), pp. 459-474,1998.

[7] P. M. Bushman and A. J. Smith, Financial accounting information and corporate governance, Journal of accounting and Economics, vol.32(1), pp.237-333, 2001. 